\title{
The remarkable effect of organic salts on 1,3,5-trioxane synthesis
}

\author{
Liu-Yi Yin ${ }^{1} \cdot$ Yu-Feng Hu${ }^{1} \cdot$ Hai-Yan Wang ${ }^{1}$
}

Received: 2 February 2016/Published online: 14 October 2016

(C) The Author(s) 2016. This article is published with open access at Springerlink.com

\begin{abstract}
The effects of organic salts on 1,3,5-trioxane synthesis were investigated through batch reaction and continuous production experiments. The organic salts used include sodium methanesulfonate $\left(\mathrm{CH}_{3} \mathrm{NaO}_{3} \mathrm{~S}\right)$, sodium benzenesulfonate $\left(\mathrm{C}_{6} \mathrm{H}_{5} \mathrm{NaO}_{3} \mathrm{~S}\right)$, sodium 4-methylbenzenesulfonate $\left(\mathrm{C}_{7} \mathrm{H}_{7} \mathrm{NaO}_{3} \mathrm{~S}\right)$, and sodium 3-nitrobenzene sulfonate $\left(\mathrm{C}_{6} \mathrm{H}_{4} \mathrm{NNaO}_{5} \mathrm{~S}\right)$. It was shown that the effects of organic salts on the yield of 1,3,5-trioxane in reaction solution and distillate follow the order $\mathrm{CH}_{3} \mathrm{NaO}_{3} \mathrm{~S}<$ $\mathrm{C}_{6} \mathrm{H}_{5} \mathrm{NaO}_{3} \mathrm{~S}<\mathrm{C}_{7} \mathrm{H}_{7} \mathrm{NaO}_{3} \mathrm{~S}<\mathrm{C}_{6} \mathrm{H}_{4} \mathrm{NNaO}_{5} \mathrm{~S}$, which is inversely related to the charge density of the anions of the organic salts. In comparison with $\mathrm{Cl}^{-}$-based salts such as magnesium chloride, organic salts have the advantages of less formic acid generation and low corrosion. Studies on water activity revealed that the effect of organic salts on the activity of water was quite small at low concentration of organic salts. UV-visible spectroscopy and vapor-liquid equilibrium experiments were performed to uncover the mechanisms that govern such effects. The results showed that the effect of organic salts on the yield of 1,3,5-trioxane relies primarily on their ability to increase the catalytic activity of sulfuric acid and increase the relative volatilities of 1,3,5-trioxane and water and of 1,3,5-trioxane and oligomers.
\end{abstract}

Yu-Feng $\mathrm{Hu}$

huyf3581@sina.com

1 State Key Laboratory of Heavy Oil Processing and High Pressure Fluid Phase Behavior and Property Research Laboratory, China University of Petroleum, Beijing 102249, China

Edited by Xiu-Qin Zhu
Keywords 1,3,5-Trioxane - Organic salt - Salt effect . Hammett function - Relative volatility

\section{Introduction}

1,3,5-Trioxane is attracting increasing attention as an alternative starting material to formaldehyde solution for preparing anhydrous formaldehyde which is used to manufacture disinfectant agents, acetal resins, bonding materials, pesticides, molding materials, antibacterial agents, etc. (Augé and Gil 2002). In particular, acetal resins are being more widely used in areas where metals were traditional, because of their superior chemical stability, mechanical strength, and plasticity (Schweitzer et al. 1959; Koch and Lindvig 1959). Accordingly, development of a more practical and economic process for production of 1,3,5-trioxane is important due to the rapid expansion of acetal resin production (Masamoto et al. 2000; Grützner et al. 2007).

In the commercial process, 1,3,5-trioxane is obtained by heating aqueous formaldehyde in the presence sulfuric acid (Masamoto et al. 2000). Although sulfuric acid is the most generally used catalyst due to its low price and the mature processing route, it has shortcomings as well. Among the more troublesome of these are the by-products such as formic acid and methyl formate. The formation of large amounts of by-products will result in a decrease in catalytic activity and of the selectivity of 1,3,5-trioxane formation, subsequently giving rise to an increase in the energy consumption during 1,3,5-trioxane synthesis. Specifically, the formic acid by-product can cause serious corrosion to equipment ( $\mathrm{Li}$ et al. 2015). Previous works (Cui 1990; Masamoto et al. 2000) report that acidic ion exchange resin and heteropolyacids have the potential to be used as the 
catalyst for 1,3,5-trioxane synthesis. Nevertheless, the reaction conditions (e.g., high formaldehyde concentration (60 wt \%) and large amount of catalyst $(50 \mathrm{wt} \%)$ make it difficult to use in pilot plant trials (Masamoto et al. 2000; Guan et al. 2005; Liu and Li 1982). Although acidic ionic liquids (ILs) have been successfully used in a pilot plant scale for the preparation of 1,3,5-trioxane (Song et al. 2012), the high price of ILs catalyst is a problem (Hu et al. 2015; Li et al. 2012). Therefore, development of a new catalytic system (sulfuric acid + assistant reagent) is the key for synthesis of 1,3,5-trioxane.

The salt effect is always a research area of interest in chemical synthesis and separation. More recently, the remarkable role of halide salt additives in the Negishi reaction involving aryl zinc reagents has been reported (McCann and Organ 2014). It is ranked as one of the world's top ten science and technology improvements in 2014 by Chemical \& Engineering News. In our previous work, a positive effect of inorganic salts has been found for the synthesis of 1,3,5-trioxane (Yin et al. 2015), and intensive studies have been carried out to explore the salt effect of various types of inorganic salt on the formation of 1,3,5-trioxane (Yin et al. 2015). The results shows that higher yields of 1,3,5-trioxane can be obtained in reaction solution by using the $\mathrm{Cl}^{-}$-based salts with smaller cation radius. It can be concluded that the enhancement in the yield of 1,3,5-trioxane is attributed to hydration which can decrease the water activity. Though these investigations covered important aspects of 1,3,5-trioxane synthesis, there is still something to be further explored, since the increase in the acid value by the addition of $\mathrm{Cl}^{-}$-based salts is still very remarkable compared to that observed for sulfuric acid alone. In addition, the presence of $\mathrm{Cl}^{-}$-based salts and the $\mathrm{HCl}$ formed may cause corrosion (Bao 2007). Therefore, in the present work we investigated the influence of organic salts on 1,3,5-trioxane synthesis by batch reaction and continuous production experiments. In addition, UVvisible spectroscopy and vapor-liquid equilibrium experiments were also performed for the first time to investigate the mechanisms that control the effects of organic salts on the yield of 1,3,5-trioxane in the reaction solution and in the distillate from the reaction.

\section{Experimental}

\subsection{1,3,5-trioxane synthesis}

The $50 \mathrm{wt} \%$ aqueous formaldehyde solution used in experiments was prepared by concentrating $\sim 37 \mathrm{wt} \%$ aqueous formaldehyde solution. The organic salts, analytical grade sodium methanesulfonate $\left(\mathrm{CH}_{3} \mathrm{NaO}_{3} \mathrm{~S}\right)$, sodium benzenesulfonate $\left(\mathrm{C}_{6} \mathrm{H}_{5} \mathrm{NaO}_{3} \mathrm{~S}\right)$, sodium 4-methylbenzenesulfonate
$\left(\mathrm{C}_{7} \mathrm{H}_{7} \mathrm{NaO}_{3} \mathrm{~S}\right)$, and sodium 3-nitrobenzenesulfonate $\left(\mathrm{C}_{6} \mathrm{H}_{4}\right.$ $\mathrm{NNaO}_{5} \mathrm{~S}$ ), supplied by Aladdin Industrial Corporation (Shanghai, China), were used without further purification. The synthesis procedures for batch reaction experiments and continuous production were similar to those we used previously (Yin et al. 2015). The 1,3,5-trioxane concentrations in the reaction mixture and distillate were analyzed by gas chromatography, applying the internal standard procedure, and the acid value was determined by acid-base titration using a potentiometric titrimeter (Leici ZDJ-5, Shanghai INESA Scientific Instrument Co. Ltd., China).

\subsection{UV-visible spectroscopy}

The acidic scales of the sulfuric acid solution containing organic salt were measured by UV-visible spectra with basic indicators according to the procedure reported by Thomazeau et al. (2003), Xing et al. (2007). UV-visible spectroscopy analysis was conducted on a Shimadzu 2550 UV-visible spectrophotometer (Shimadzu Corporation, Japan).

\subsection{Vapor-liquid equilibrium (VLE) experiments}

In the present VLE experiments, a modified Othmer still was used as described by Morrison et al. (1990). The Othmer still was operated at atmospheric pressure $(101.3 \mathrm{kPa})$. In each experimental run, $50 \mathrm{wt} \%$ formaldehyde solution containing $3 \mathrm{wt} \%$ 1,3,5-trioxane and $0.2 \mathrm{~mol} \mathrm{~L}^{-1}$ organic salts was added to the still which was heated in an oil bath. A steady state was usually reached after $1 \mathrm{~h}$ of operation. Then samples of the coexisting phases of the quaternary system (formaldehyde $+1,3,5$ trioxane + organic salt + water) were taken from vapor and liquid sampling ports and analyzed. Thus, the relative volatility can by defined by

$\alpha_{2}=\frac{y_{2} / x_{2}}{y_{1} / x_{1}}$

where $x_{i}$ and $y_{i}$ are, respectively, the liquid- and vaporphase compositions of species at equilibrium.

\section{Results and discussion}

The reproducibility of the batch reaction experiments has been studied, and the result was highly satisfactory (Yin et al. 2015).

Therefore, the effects of organic salts on the yield of 1,3,5-trioxane and the formation of by-product(s) in the reaction solution were investigated by batch experiments. Figure 1 shows the results obtained by adding various organic salts. 


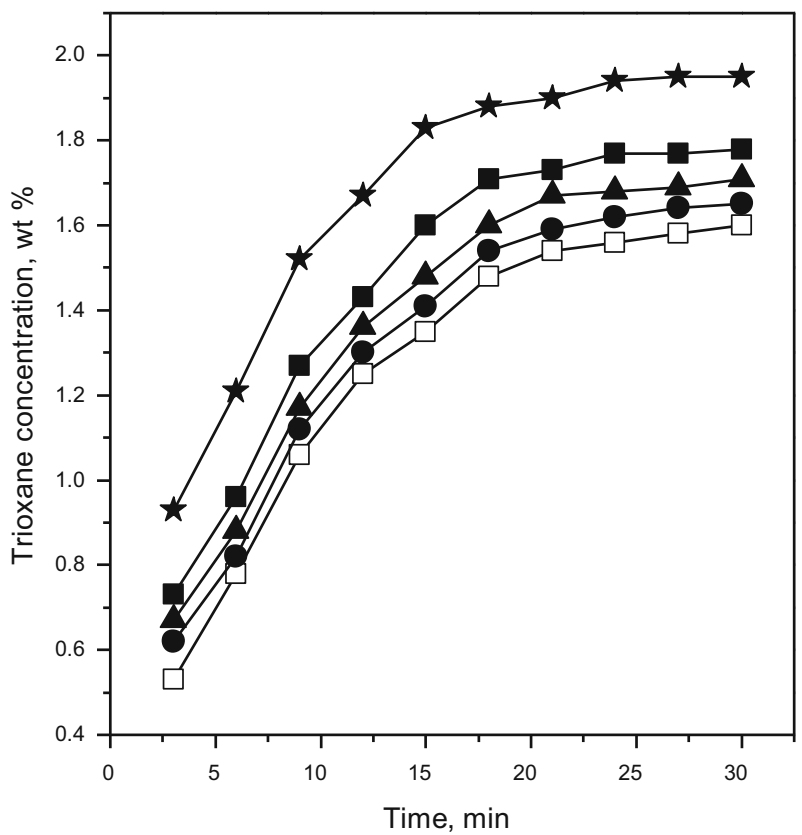

Fig. 1 Effects of organic salts on the yield of 1,3,5-trioxane in the reaction solution $\left(50 \mathrm{wt} \%\right.$ formaldehyde- $0.4 \mathrm{~mol} \mathrm{~L} \quad \mathrm{~L}^{-1} \quad \mathrm{H}_{2} \mathrm{SO}_{4}$ $0.2 \mathrm{~mol} \mathrm{~L}-1$ organic salt). Filled circle $\mathrm{CH}_{3} \mathrm{NaO}_{3} \mathrm{~S}$; filled triangle $\mathrm{C}_{6} \mathrm{H}_{5} \mathrm{NaO}_{3} \mathrm{~S}$; filled square $\mathrm{C}_{7} \mathrm{H}_{7} \mathrm{NaO}_{3} \mathrm{~S}$; filled star $\mathrm{C}_{6} \mathrm{H}_{4} \mathrm{NNaO}_{5} \mathrm{~S}$; open square salt-free

The changes in 1,3,5-trioxane concentration shown in Fig. 1 indicated that the addition of $\mathrm{CH}_{3} \mathrm{NaO}_{3} \mathrm{~S}, \mathrm{C}_{6} \mathrm{H}_{5}$ $\mathrm{NaO}_{3} \mathrm{~S}, \quad \mathrm{C}_{7} \mathrm{H}_{7} \mathrm{NaO}_{3} \mathrm{~S}$, or $\mathrm{C}_{6} \mathrm{H}_{4} \mathrm{NNaO}_{5} \mathrm{~S}$ remarkably increased the 1,3,5-trioxane concentration in the reaction solution (formaldehyde- $\mathrm{H}_{2} \mathrm{SO}_{4}$-organic salt) in comparison with the results obtained in the salt-free system (formaldehyde- $\mathrm{H}_{2} \mathrm{SO}_{4}$ ).

To quantitatively represent the salt effect on the yield of 1,3,5-trioxane in the reaction solution, the rate constant $(k)$ was determined by fitting 1,3,5-trioxane concentration in the reaction solution $\left(c_{p}\right)$ as a function of reaction time according to the reaction dynamics model Eq. (2) (Cui 1990):

$\mathrm{d} c_{p} / \mathrm{d} t=k_{1} c_{\mathrm{A}}^{3}-k_{2} c_{p}$

where $k_{1}$ and $k_{2}$ are, respectively, the rate constants for the forward reaction and the reverse reaction and $c_{\mathrm{A}}$ is the formaldehyde concentration in reaction solution.

Consequently, the effect of the organic salts mentioned in Table 1 on 1,3,5-trioxane formation can be quantitatively represented by the ratio $k_{\text {salt }} / k$, where $k_{\text {salt }}$ and $k$ are the rate constants for the salt-containing solution and for the salt-free solution, respectively, and the results are shown in Table 1 , which include the ratio $k_{\text {salt }} / k$ for inorganic salt $\mathrm{MgCl}_{2}$ for the sake of comparison.

The values of ratio $k_{\text {salt }} / k$ shown in Table 1 indicate that the influence of organic salts on the formation of 1,3,5-
Table 1 Effect of the organic salts on the formation of 1,3,5-trioxane catalyzed by sulfuric acid at $98^{\circ} \mathrm{C}$

\begin{tabular}{lll}
\hline Salt & $k_{1, \text { salt }} / k_{1}$ & $k_{2, \text { salt }} / k_{2}$ \\
\hline $\mathrm{CH}_{3} \mathrm{NaO}_{3} \mathrm{~S}$ & 1.09 & 1.07 \\
$\mathrm{C}_{6} \mathrm{H}_{5} \mathrm{NaO}_{3} \mathrm{~S}$ & 1.18 & 1.12 \\
$\mathrm{C}_{7} \mathrm{H}_{7} \mathrm{NaO}_{3} \mathrm{~S}$ & 1.32 & 1.21 \\
$\mathrm{C}_{6} \mathrm{H}_{4} \mathrm{NNaO}_{5} \mathrm{~S}$ & 1.59 & 1.39 \\
$\mathrm{MgCl}_{2}$ & 1.64 & 1.41 \\
\hline
\end{tabular}

trioxane follows the order of $\mathrm{CH}_{3} \mathrm{NaO}_{3} \mathrm{~S}<\mathrm{C}_{6} \mathrm{H}_{5} \mathrm{NaO}_{3} \mathrm{~S}$ $<\mathrm{C}_{7} \mathrm{H}_{7} \mathrm{NaO}_{3} \mathrm{~S}<\mathrm{C}_{6} \mathrm{H}_{4} \mathrm{NNaO}_{5} \mathrm{~S}<\mathrm{MgCl}_{2}$, which is inversely related to the charge density of the anions of the salts (the value of the acid dissociation constant $\mathrm{p} K_{\mathrm{a}}$ decreases in the order of $\mathrm{CH}_{4} \mathrm{O}_{3} \mathrm{~S}>\mathrm{C}_{6} \mathrm{H}_{6} \mathrm{O}_{3} \mathrm{~S}>\mathrm{C}_{7} \mathrm{H}_{8} \mathrm{O}_{3} \mathrm{~S}$ $>\mathrm{C}_{6} \mathrm{H}_{5} \mathrm{NO}_{5} \mathrm{~S}>\mathrm{HCl}$ ) (Guthrie 1978).

Although the influence of $\mathrm{MgCl}_{2}$ on 1,3,5-trioxane formation was greater than that exerted by $\mathrm{C}_{6} \mathrm{H}_{4} \mathrm{NNaO}_{5} \mathrm{~S}$, the acid value in solution of $50 \mathrm{wt} \%$ formaldehyde$0.4 \mathrm{~mol} \mathrm{~L}^{-1} \mathrm{H}_{2} \mathrm{SO}_{4}-0.2 \mathrm{~mol} \mathrm{~L}^{-1} \mathrm{C}_{6} \mathrm{H}_{4} \mathrm{NNaO}_{5} \mathrm{~S}$ was considerably smaller than that in the solution of $50 \mathrm{wt} \%$ formaldehyde- $0.4 \mathrm{~mol} \mathrm{~L}^{-1} \mathrm{H}_{2} \mathrm{SO}_{4}-0.2 \mathrm{~mol} \mathrm{~L}^{-1} \mathrm{MgCl}_{2}$ ), as is demonstrated in Fig. 2. These comparisons revealed that $\mathrm{C}_{6} \mathrm{H}_{4} \mathrm{NNaO}_{5} \mathrm{~S}$ had superior advantages over inorganic salts like $\mathrm{MgCl}_{2}$ in 1,3,5-trioxane synthesis.

The control mechanisms for the effect of the organic salts on 1,3,5-trioxane formation in the reaction solutions are very complex. According to the mechanism proposed in

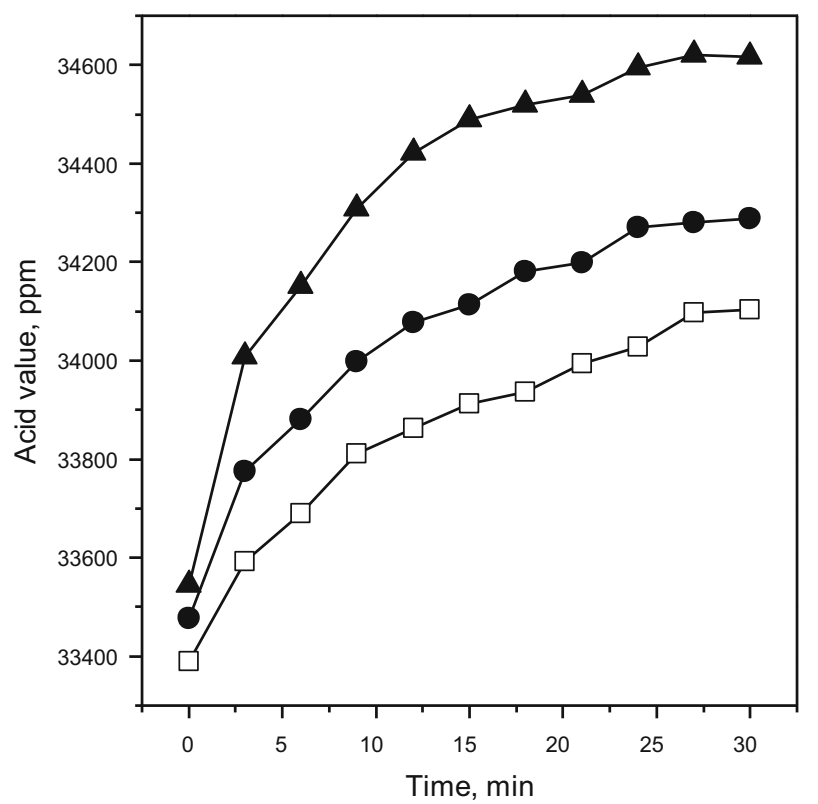

Fig. 2 Effect of salts on the change in the acid value of the reaction solution (50 wt\% formaldehyde- $0.4 \mathrm{~mol} \mathrm{~L}^{-1} \mathrm{H}_{2} \mathrm{SO}_{4}-0.2 \mathrm{~mol} \mathrm{~L}^{-1}$ salt). Filled triangle $\mathrm{MgCl}_{2}$; filled circle $\mathrm{C}_{6} \mathrm{H}_{4} \mathrm{NNaO}_{5} \mathrm{~S}$; open square salt-free 
Table 2 Activity of water in the binary solution (organic salt $-\mathrm{H}_{2} \mathrm{O}$ ) at $25{ }^{\circ} \mathrm{C}$

\begin{tabular}{lll}
\hline Organic salts, $0.2 \mathrm{~mol} \mathrm{~kg}^{-1}$ & Osmotic coefficients & Activity of water \\
\hline $\mathrm{CH}_{3} \mathrm{SO}_{3} \mathrm{Na}$ & 0.925 & 0.993 \\
$\mathrm{C}_{6} \mathrm{H}_{5} \mathrm{SO}_{3} \mathrm{Na}$ & 0.932 & 0.993 \\
$\mathrm{C}_{7} \mathrm{H}_{7} \mathrm{SO}_{3} \mathrm{Na}$ & 0.908 & 0.993 \\
$\mathrm{C}_{6} \mathrm{H}_{4} \mathrm{NNaO}_{5} \mathrm{~S}$ & 0.938 & 0.993 \\
\hline
\end{tabular}

our previous paper (Yin et al. 2015), the addition of a salt to the reaction solution would decrease the activity of water in the solution and therefore favor the forward reaction of Eq. (3).

$\mathrm{HO}\left(\mathrm{CH}_{2} \mathrm{O}\right)_{3} \mathrm{H} \stackrel{\mathrm{H}^{+}}{\leftrightarrows}\left(\mathrm{CH}_{2} \mathrm{O}\right)_{3}+\mathrm{H}_{2} \mathrm{O}$

The influence of organic salt on the water activity of the reaction solution can be reflected by the calculated value of activity of water for binary system (organic salt + water) at $25{ }^{\circ} \mathrm{C}$, which is shown in Table 2 (Walter and Wu 1972; Bonner 1981).

Table 2 indicates that these organic salts do not decrease the water activity of the reaction solution (formaldehyde$\mathrm{H}_{2} \mathrm{SO}_{4}$-organic salt) at such low concentration of organic salts. However, the addition of these salts can significantly increase 1,3,5-trioxane concentration in the reaction solution. For example, for the same water activity of 0.993 , the concentration of 1,3,5-trioxane at $t_{r}=30 \mathrm{~min}$ is $1.65 \mathrm{wt} \%$ by $\mathrm{C}_{6} \mathrm{H}_{5} \mathrm{NaO}_{3} \mathrm{~S}$, while 1.93 wt $\%$ by $\mathrm{C}_{6} \mathrm{H}_{4} \mathrm{NNaO}_{5} \mathrm{~S}$. These results mean that the salt effect on the yield of 1,3,5-trioxane in the reaction solution cannot be solely understood by their ability to decrease the activity of water in the reaction solution.

Table 3 Calculation of the Hammett function in sulfuric acid solution containing various salts

\begin{tabular}{lllll}
\hline Sulfuric acid and organic salt & $A_{\max }$ & {$[\mathrm{I}]^{\mathrm{b}}, \%$} & {$\left[\mathrm{IH}^{+}\right]^{\mathrm{c}}, \%$} & $H_{0}^{\mathrm{d}}$ \\
\hline $\mathrm{a}$ & 0.809 & 100 & 0 & \\
$\mathrm{H}_{2} \mathrm{SO}_{4}$ & 0.643 & 0.795 & 0.205 & 0.299 \\
$\mathrm{H}_{2} \mathrm{SO}_{4}+\mathrm{CH}_{3} \mathrm{NaO}_{3} \mathrm{~S}$ & 0.636 & 0.786 & 0.214 & 0.275 \\
$\mathrm{H}_{2} \mathrm{SO}_{4}+\mathrm{C}_{6} \mathrm{H}_{5} \mathrm{NaO}_{3} \mathrm{~S}$ & 0.632 & 0.781 & 0.219 & 0.262 \\
$\mathrm{H}_{2} \mathrm{SO}_{4}+\mathrm{C}_{7} \mathrm{H}_{7} \mathrm{NaO}_{3} \mathrm{~S}$ & 0.630 & 0.779 & 0.221 & 0.257 \\
$\mathrm{H}_{2} \mathrm{SO}_{4}+\mathrm{C}_{6} \mathrm{H}_{4} \mathrm{NNaO}_{5} \mathrm{~S}$ & 0.628 & 0.776 & 0.224 & 0.250 \\
$\mathrm{H}_{2} \mathrm{SO}_{4}+\mathrm{MgCl}_{2}$ & 0.627 & 0.775 & 0.225 & 0.247 \\
\hline
\end{tabular}

a The total unprotonated form of the indicator (when no acid and salts are added to the solution of indicator)

b, c $[\mathrm{I}]$ and $\left[\mathrm{IH}^{+}\right]$are the molar concentrations of, respectively, the unprotonated and protonated form of 2-nitroaniline indicator in aqueous solution

${ }^{\mathrm{d}} H_{0}=\mathrm{p} K(\mathrm{I})_{\mathrm{aq}}+\log \left([\mathrm{I}] /\left[\mathrm{IH}^{+}\right]\right)$, where $\mathrm{p} K(\mathrm{I})_{\mathrm{aq}}$ is the $\mathrm{p} K_{\mathrm{a}}$ value of the indicator referred to an aqueous solution
UV-visible experiments were performed to further uncover the mechanism that controls the effect of salts on the formation of 1,3,5-trioxane. The typical spectra are shown in Fig. 3, which discloses that the absorbance of the unprotonated form of the indicator 2-nitroaniline is weak in salt-containing solution compared to the sample of the indicator in salt-free solution.

By taking the total unprotonated form of the indicator as the initial reference, the Hammett function $\left(H_{0}\right)$ for sulfuric acid solution containing various salts was calculated via the $[\mathrm{I}] /\left[\mathrm{IH}^{+}\right]$ratio determined from the measured absorbances $\left(A_{\max }\right)$ (see Table 3). According to Fig. 3 and Table 3, the addition of organic salts to the sulfuric acid solution decreased the Hammett function of the solution (i.e., increased catalytic activity of sulfuric acid). The Hammett function for sulfuric acid solution containing various salts increased in the order of $\mathrm{CH}_{3} \mathrm{NaO}_{3} \mathrm{~S}<\mathrm{C}_{6} \mathrm{H}_{5} \mathrm{NaO}_{3} \mathrm{~S}$ $<\mathrm{C}_{7} \mathrm{H}_{7} \mathrm{NaO}_{3} \mathrm{~S}<\mathrm{C}_{6} \mathrm{H}_{4} \mathrm{NNaO}_{5} \mathrm{~S}<\mathrm{MgCl}_{2}$, which is consistent with the order for the effect of organic salts on 1,3,5-trioxane concentration in the reaction solution (see

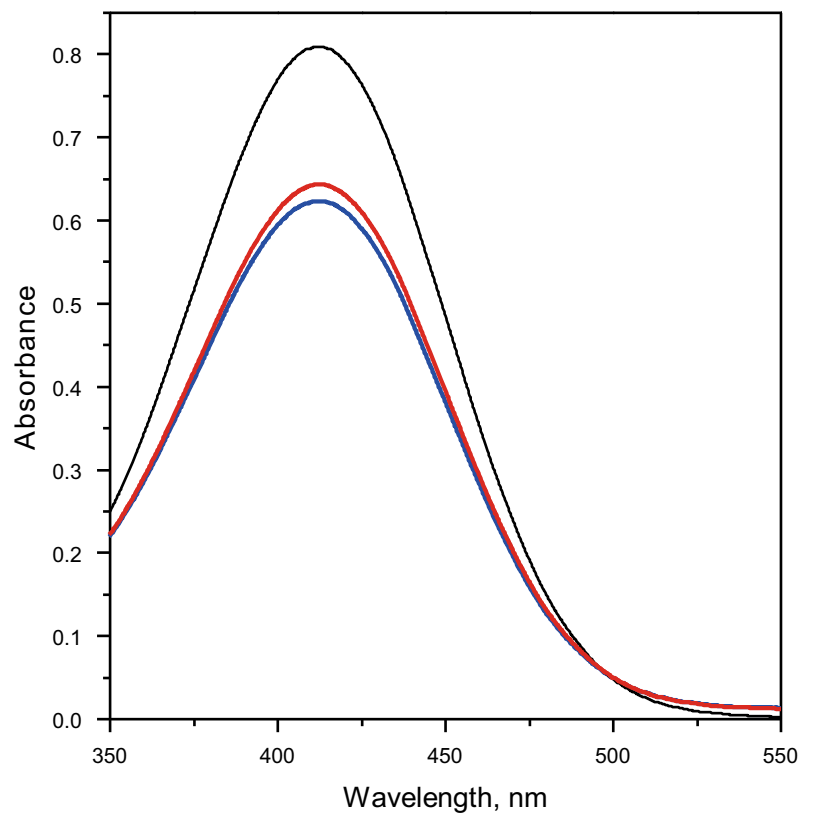

Fig. 3 Absorption spectra of 2-nitroaniline for various solutions. Black curve the total unprotonated form of the indicator; red curve sulfuric acid solution; blue curve sulfuric acid solution containing $\mathrm{CH}_{3} \mathrm{NaO}_{3} \mathrm{~S}$ 
Table 4 Effect of the added salt on the conversion and time/ space yield for 1,3,5-trioxane production

\begin{tabular}{|c|c|c|}
\hline Acid and salt & Conversion $^{\mathrm{a}}, \%$ & Time/space yield ${ }^{\mathrm{b}}, \mathrm{g} \mathrm{h}^{-1} \mathrm{~L}^{-1}$ \\
\hline $\mathrm{H}_{2} \mathrm{SO}_{4}$ & 19.00 & 46.28 \\
\hline $\mathrm{H}_{2} \mathrm{SO}_{4}+\mathrm{CH}_{3} \mathrm{NaO}_{3} \mathrm{~S}$ & 20.54 & 48.36 \\
\hline $\mathrm{H}_{2} \mathrm{SO}_{4}+\mathrm{C}_{6} \mathrm{H}_{5} \mathrm{NaO}_{3} \mathrm{~S}$ & 22.50 & 51.04 \\
\hline $\mathrm{H}_{2} \mathrm{SO}_{4}+\mathrm{C}_{7} \mathrm{H}_{7} \mathrm{NaO}_{3} \mathrm{~S}$ & 24.11 & 54.43 \\
\hline $\mathrm{H}_{2} \mathrm{SO}_{4}+\mathrm{C}_{6} \mathrm{H}_{4} \mathrm{NNaO}_{5} \mathrm{~S}$ & 27.71 & 58.72 \\
\hline $\mathrm{H}_{2} \mathrm{SO}_{4}+\mathrm{MgCl}_{2}$ & 28.69 & 60.38 \\
\hline
\end{tabular}

a The percent of 1,3,5-trioxane converted

b The amount of 1,3,5-trioxane formed per hour in 11 of solution
Fig. 1) and the order for the value of $\left(k_{1, \text { salt }} / k_{1}\right) /\left(k_{2, \text { salt }} / k_{2}\right) \quad(=1.02,1.05,1.09,1.14,1.16$, respectively, see Table 1). In other words, the effect of these salts on the yield of 1,3,5-trioxane relies primarily on their ability to increase the catalytic activity of sulfuric acid solution, as demonstrated in Table 3.

For the continuous production of 1,3,5-trioxane, the results are summarized in Table 4, which also include the results for $\mathrm{MgCl}_{2}$ for the sake of comparison.

The values of conversion and time/space yield shown in Table 4 indicate that the addition of the organic salts increased the yield of 1,3,5-trioxane in the reaction distillate. Furthermore, such positive effects increased in the order of $\mathrm{CH}_{3} \mathrm{NaO}_{3} \mathrm{~S}<\mathrm{C}_{6} \mathrm{H}_{5} \mathrm{NaO}_{3} \mathrm{~S}<\mathrm{C}_{7} \mathrm{H}_{7} \mathrm{NaO}_{3} \mathrm{~S}<$ $\mathrm{C}_{6} \mathrm{H}_{4} \mathrm{NNaO}_{5} \mathrm{~S}<\mathrm{MgCl}_{2}$. In the continuous production process, the formed 1,3,5-trioxane was removed from the system by means of azeotropic distillation with water to enhance the separation. Thus, the influences of the organic salts on the conversion and time/space yield can be attributed to many more influencing factors. In addition to their effect on the yield of 1,3,5-trioxane in the reaction solution as discussed above, the vapor-liquid phase equilibrium experiments revealed that the organic salts can also increase the relative volatility of 1,3,5-trioxane and water and of 1,3,5-trioxane and formaldehyde, which is shown in Table 5. Relative volatility is related to the interactions

Table 5 Effect of the organic salts on the relative volatility $(\alpha)$ of 1,3,5-trioxane (2) and water (4) and of 1,3,5-trioxane (2) and formaldehyde (1) in the system [formaldehyde (1)-1,3,5-trioxane (2)organic salt (3)-water (4)]

\begin{tabular}{lll}
\hline Organic salt, $0.2 \mathrm{~mol} \mathrm{~kg}^{-1}$ & $\alpha_{24}$ & $a_{21}$ \\
\hline a & 4.0506 & 6.1711 \\
$\mathrm{CH}_{3} \mathrm{NaO}_{3} \mathrm{~S}$ & 4.4763 & 7.3562 \\
$\mathrm{C}_{6} \mathrm{H}_{5} \mathrm{NaO}_{3} \mathrm{~S}$ & 4.5411 & 7.4864 \\
$\mathrm{C}_{7} \mathrm{H}_{7} \mathrm{NaO}_{3} \mathrm{~S}$ & 4.6782 & 7.6566 \\
$\mathrm{C}_{6} \mathrm{H}_{4} \mathrm{NNaO}_{5} \mathrm{~S}$ & 4.7836 & 7.8072 \\
\hline
\end{tabular}

Formaldehyde concentration is $50 \mathrm{wt} \%, 1,3,5$-trioxane concentration $3 \mathrm{wt} \%$, temperature $98{ }^{\circ} \mathrm{C}$

a (formaldehyde-1,3,5-trioxane-water) system between 1,3,5-trioxane and the coexisting species. Due to the lack of the $-\mathrm{OH}$ group(s) in the molecular structure of 1,3,5-trioxane, the interactions between 1,3,5-trioxane and the coexisting ions of the salt are considerably smaller than those between water (or formaldehyde) and these ions. Therefore, 1,3,5-trioxane shows a very high volatility compared to formaldehyde and water.

\section{Conclusions}

The effects of organic salts on the yield of 1,3,5-trioxane in the reaction solution were investigated by batch reaction experiments. The results showed that the addition of $\mathrm{CH}_{3} \mathrm{NaO}_{3} \mathrm{~S}, \mathrm{C}_{6} \mathrm{H}_{5} \mathrm{NaO}_{3} \mathrm{~S}, \mathrm{C}_{7} \mathrm{H}_{7} \mathrm{NaO}_{3} \mathrm{~S}$, and $\mathrm{C}_{6} \mathrm{H}_{4} \mathrm{NNaO}_{5} \mathrm{~S}$ to the reaction solution could considerably increase the yield of 1,3,5-trioxane in the reaction solution. The effect of these salts increased in the order of $\mathrm{CH}_{3} \mathrm{NaO}_{3} \mathrm{~S}<$ $\mathrm{C}_{6} \mathrm{H}_{5} \mathrm{NaO}_{3} \mathrm{~S}<\mathrm{C}_{7} \mathrm{H}_{7} \mathrm{NaO}_{3} \mathrm{~S}<\mathrm{C}_{6} \mathrm{H}_{4} \mathrm{NNaO}_{5} \mathrm{~S}$, which is inversely related to the charge density of the anions of the corresponding salts. The mechanisms that control such effects were systematically studied through calculation of the activity of water and experiments of acidity measurement. The calculated water activity indicated that these organic salts had almost no effect on the activity of water of the reaction solution. The results of acidity measurement experiments showed that the Hammett function for sulfuric acid solution containing various salts increased in the order of $\mathrm{CH}_{3} \mathrm{NaO}_{3} \mathrm{~S}<\mathrm{C}_{6} \mathrm{H}_{5} \mathrm{NaO}_{3} \mathrm{~S}<\mathrm{C}_{7} \mathrm{H}_{7} \mathrm{NaO}_{3} \mathrm{~S}<\mathrm{C}_{6} \mathrm{H}_{4} \mathrm{NNa}$ $\mathrm{O}_{5} \mathrm{~S}<\mathrm{MgCl}_{2}$, which agreed well with the order for the effect of organic salts on 1,3,5-trioxane concentration in the reaction solution.

The influence of organic salts mentioned above on the yield of 1,3,5-trioxane in the reaction distillate was also investigated by continuous production experiments. These salts showed a positive effect on the yield of 1,3,5-trioxane in the distillate, and their effect increased in the order of $\mathrm{CH}_{3} \mathrm{NaO}_{3} \mathrm{~S}<\mathrm{C}_{6} \mathrm{H}_{5} \mathrm{NaO}_{3} \mathrm{~S}<\mathrm{C}_{7} \mathrm{H}_{7} \mathrm{NaO}_{3} \mathrm{~S}<\mathrm{C}_{6} \mathrm{H}_{4} \mathrm{NNaO}_{5} \mathrm{~S}$. Such an effect is related to the increase in relative volatility, which is verified by vapor-liquid phase 
experiments for the system (formaldehyde-1,3,5-trioxaneorganic salt-water).

Acknowledgments We acknowledge the National Natural Science Foundation of China (21576285 and 21276271) and Science Foundation of China University of Petroleum, Beijing (qzdx-2011-01), for financial support.

Open Access This article is distributed under the terms of the Creative Commons Attribution 4.0 International License (http://crea tivecommons.org/licenses/by/4.0/), which permits unrestricted use, distribution, and reproduction in any medium, provided you give appropriate credit to the original author(s) and the source, provide a link to the Creative Commons license, and indicate if changes were made.

\section{References}

Augé J, Gil R. A convenient solvent-free preparation of 1,3,5trioxanes. Tetrahedron Lett. 2002;43(44):7919-20.

Bonner OD. Study of methanesulfonates and trifluoromethanesulfonates evidence for hydrogen bonding to the trifluoro group. J Am Chem Soc. 1981;103(12):3262-5.

Bao QN. The relationship between chloride ion and the corrosion of stainless steel in cooling water system. Ind Water Treat. 2007;27(7):1.

Cui YL. Kinetics study of synthesis of trioxane from formaldehyde with A-15 catalyst. Petrochem Petrochem Technol. 1990;19(4):214-8.

Guan J, Lin L, Zeng CY. Trioxane synthesis from formaldehyde over the supported PW12/AC catalyst. Nat Gas Chem Ind. 2005;30(4):19-22.

Grützner T, Hasse H, Lang N, Siegert M, Ströfer E. Development of a new industrial process for trioxane production. Chem Eng Sci. 2007;62(18):5613-20.

Guthrie JP. Hydrolysis of esters of oxy acids: $\mathrm{p} K_{\mathrm{a}}$ values for strong acids; Brønsted relationship for attack of water at methyl; free energies of hydrolysis of esters of oxy acids; and a linear relationship between free energy of hydrolysis and $\mathrm{p} K_{\mathrm{a}}$ holding over a range of $20 \mathrm{pK}$ units. Can J Chem. 1978;56:2342-54.
Hu JJ, Zhao DS, Li JJ, Zhai JH, Hu TT. Synthesis and catalytic esterification performance of caprolactam task-specific ionic liquids. Chin J Org Chem. 2015;35(8):1773-80.

Koch TA, Lindvig PE. Molecular structure of high molecular weight acetal resins. J Appl Polym Sci. 1959;1(2):164-8.

Li Z, Chen J, Xia CG. Advances in industrial application of ionic liquids. Chem Ind Eng Prog. 2012;31(10):2113-82.

Li Z, Luo CB, Yu XM, Liu W, Liu Q, Yang B. Corrosion behavior of carbon steel in high temperature and high pressure formic acid environment. Corros Prot. 2015;36(6):540-6.

Liu HH, Li CL. A study of side reactions in synthesis of trioxymethylene with Anlberlyst-15. Chem Word. 1982;2:41-4.

Morrison JF, Baker JC, Meredith HC III, Newman KE, Waiter TD, Massle JD, Perry RL, Cummings PT. Experimental measurement of vapor-liquid equilibrium in alcohol/water/salt Systems. J Chem Eng Data. 1990;35(4):395.

Masamoto J, Hamanaka K, Yoshida K, Nagahara H, Kagawa K, Iwaisako T, Komaki H. Synthesis of trioxane using heteropolyacids as catalyst. Angew Chem Int Ed. 2000;39(12):2102-4.

McCann LC, Organ MG. On the remarkably different role of salt in the cross-coupling of arylzincs from that seen with alkylzincs. Angew Chem Int Ed. 2014;53(17):4386-9.

Schweitzer CE, Macdonald RN, Punderson JO. Thermally stable high molecular weight polyoxymethylenes. J Appl Polym Sci. 1959;1(2):158-63.

Song HY, Chen J, Xia CG, Li Z. Novel acidic ionic liquids as efficient and recyclable catalysts for the cyclotrimerization of aldehydes. Synth Commun. 2012;42(2):266-73.

Thomazeau C, Olivier-Bourbigou H, Magna L, Luts S, Gilbert B. Determination of an acidic scale in room temperature ionic liquids. J Am Chem Soc. 2003;125(18):5264-5.

Walter JH, Wu YC. Osmotic coefficients and mean activity coefficients of uni-univalent electrolytes in water at $25^{\circ} \mathrm{C}$. J Phys Chem Ref Data. 1972;1(4):1074-100.

Xing HB, Wang T, Zhou ZH, Dai YY. The sulfonic acid-functionalized ionic liquids with pyridinium cations: acidities and their acidity-catalytic activity relationships. J Mol Catal A Chem. 2007;264:53-9.

Yin LY, Hu YF, Zhang XM, Qi JG, Ma WT. The salt effect on the yields of trioxane in reaction solution and in distillate. RSC Adv. 2015;5(47):37697-702. 